577 с. - 500 экз. - ISBN 966-7802-52-3.

2. Dixon L.E. TEOSINTE BRANCHED1 regulates inflorescence architecture and development in bread wheat (Triticum aestivum) / L.E. Dixon, J.R. Greenwood, S. Bencivenga, P. Zhang, J. Cockram, G. Mellers, K. Ramm, C. Cavanagh, S.M. Swain, S.A. Boden // Plant Cell - № 3 (30) - 2018. - P. 563-581. doi: 10.1105/tpc.17.00961

3. Gustafsson A. Dominance and over dominance in phytotron analysis of monohybrid barley / A. Gustafsson, I. Dormling // Hereditas - Vol. 70, № 2. - 1972. - P. 185 - 190.

4. Цильке Р.А. Изменчивость и наследование продолжительности периода всходы - колошение у эколого-отдаленных гибридов мягкой яровой пшеницы / Р.А. Цильке, И.В. Кондратьева // Актуальные задачи селекции и семеноводства сельскохозяйственных растений на современном этапе: Доклады и сообщения IX генетикоселекционной школы - Новосибирск, 2005. - С. 195-203.

5. Мережко А.Ф. Система генетического изучения исходного материала для селекции растений: (Метод. указания) / Сост. А.Ф. Мережко. - Л.: ВИР, 1984. - 70 с.

6. Костылев П.И. Генетический анализ в селекции сельскохозяйственных культур / П.И. Костылев, Л.М. Костылева. - Зерноград: ФГОУ ВПО АЧГАА, 2008. - 73 с.

DOI 10.18699/GPB2020-18

\title{
Поиск и функциональный анализ генов с циркадным паттерном экспрессии у мягкой пшеницы
}

Брагина М.К., м.н.с.; Киселёва А.А., к.б.н., н.с.; Салина Е.А., о.б.н., г.н.с. ИЦиГ СО РАН, Новосибирск, Россия.

e-mail: koltunova@bionet.nsc.ru

Циркадные ритмы регулируют многие аспекты физиологии растений, включая фотосинтез, цвветение, развитие и метаболизм. Поскольку циркадные часы координируют экспрессию ряда ключевых генов, контролируюших важные для сельского хозяйства признаки, основные гены, контролируюшие цииркадные ритмы являются цуентрами важных транскрипциионных сетей. Модификация этих генов может привести к системньм эффектам, которые обеспечат усиление адаптации и положительно повлияют на цельй ряд агрономических признаков. Таким образом, основной темой данной работы является изучение суточных колебаний транскриптома пшеницы, идентификация как основных циикадных генов, так и генов метаболических путей под влиянием суточных ритмов.

Ключевье слова: Triticum aеstivum, цุиркаднье ритмы, экспрессия генов.

\section{Detection and functional analysis of genes with circadian expression pattern in common wheat}

Bragina M.K., Kiseleva A.A., Salina E.A.

Institute of Cytology and Genetics SB RAS, Novosibirsk, Russia. 
Circadian rhythms regulate many aspects of plant physiology, including photosynthesis, flowering, development, and metabolism. Because the circadian clock coordinates the expression of a number of key genes that control traits important to agriculture, the main genes that control circadian rhythms are centers of important transcriptional networks. Modification of these genes can lead to systemic effects that enhance adaptation and positively affect a range of agronomic traits. Thus, the main topic of this work is the study of diurnal fluctuations of the wheat transcriptome, identification of both the main circadian genes and genes of metabolic pathways under the influence of diurnal rhythms.

Key words: Triticum aestivum, circadian rhythms, gene expression.

Циркадные ритмы растений координируют такие физиологические процессы, как рост, переход к цветению, фотосинтез, реакцию на стресс, метаболизм и передачу сигналов фитогормонов при суточных и сезонных изменениях условий окружающей среды [1]. Такая взаимосвязь положительно влияет на рост, развитие растений и их адаптацию. Гены, регулируемые циркадными ритмами, включают в себя гены ассимиляции СО2, накопления/деградации крахмала в листьях и хранения питательных веществ (липидов и жирных кислот) в семенах [2]. Таким образом, большая часть транскриптома растений контролируется циркадными ритмами, которые играют важную роль в суточной регуляции физиологических процессов растений. Транскриптомный анализ циркадных механизмов и их влияния на различные метаболические процессы был проведен для таких растений, как арабидопсис, пекинская капуста и соя [3-5]. Гены центрального осциллятора консервативны, и их взаимодействия очень похожи у разных видов растений, но тем не менее, существуют и видоспецифичные различия. Кроме того, у большинства видов растений гены метаболических путей, на которые влияют циркадные ритмы, очень слабо изучены.

Цель работы. Мягкая пшеница является аллополиплоидом (геном AABBDD), поэтому присутствие гомеологических генов в геноме может оказывать сильное влияние на функционирование и регуляцию циркадных ритмов. Анализ литературы и поиск в базах данных не нашли исследований, изучающих суточную экспрессию транскриптома пшеницы, информация о суточной экспрессии генов и их взаимодействии практически отсутствует. Целью данной работы было исследование суточных осцилляций транскриптома пшеницы, выявление генов различных метаболических путей, находящихся под действием суточных ритмов. Полученные знания в области генетики мягкой пшеницы могут быть использованы в фундаментальных и в прикладных исследованиях, для работ по созданию высокоадаптивных сортов мягкой пшеницы.

Материал и методы. Для идентификации генов, которые демонстрируют ритмичные изменения экспрессии в течение суток, были использованы 
данные транскриптома мягкой пшеницы сорта Chinese Spring, полученные в четырех точках в течение дня $(0,3,9,16$ часов от момента включения света) на стадии трех листьев на 21 день после прорастания. Каждая временная точка была представлена тремя биологическими повторностями. 12 библиотек было получено с использованием набора TruSeq Stranded mRNA LT Sample Prep Kit (Il-lumina). Средний объем полученных в результате одноконцевого секвенирова-ния (75 п.н.) данных на приборе Illumina NextSeq 550 (ИЦиГ СО РАН) составил порядка 35,292,368 (от 25,176,261 до 45,139,550) последовательностей. При этом среднее значение показателя качества Q составило 34.5.

После предварительной обработки и контроля качества данных с использованием утилиты FASTXtoolkit полученные последовательности были карти-рованы на референсный транскриптом пшеницы с использованием программного обеспечения Bowtie. Для количественной оценки транскриптов использовалось программное обеспечение Kallisto v0.42.3 с параметрами по умолчанию. Нормализация обогащенности экспрессии транскриптов выборок выполнена по значению ТРМ (Transcripts per million). Для идентификации генов с циркадным паттерном экспресии была использована программа JTK-CYCLE. Визуализация полученных данных проведена в программе CemiTool. Для проведения функционального анализа обогащения терминами генной онтологии групп ге-нов с различными паттернами суточной экспрессии использованы базы данных REViGO и g:Profiler.

Результаты и обсуждение. Системный анализ транскриптома пшеницы позволил идентифицировать гены, экспрессирующиеся по циркадному типу, и контролируемые ими метаболические пути: биосинтез клеточных аминокислот, фотосинтез, реакция на свет, производство метаболитов и энергии, реакция на абиотический раздражитель, метаболизм соединений азота, углеводный обмен. Было показано, что значительная часть транскриптома находится под контролем суточных ритмов, и экспрессия этих генов может сильно варьировать в зависимости от времени. Мы обнаружили семь характерных паттернов экспрессии, характеризующиеся пиками в разные моменты времени, и описали гены, лежащие в основе этих паттернов. Мы проанализировали обогащение терминов генной онтологии различными паттернами и описали основные метаболические пути в каждой группе.

Благодарности: Исследование выполнено при финансовой поддержке РФФИ в рамках научного проекта № 20-316-80003 мол_эв_а.

\section{Список литературы}

1. Covington M.F. Global transcriptome analysis reveals circadian regulation of key pathways in plant growth and development / M.F. Covington, J.N. Maloof, M. Straume et al. // Genome Biol., 2008, vol. 9, No. 8. 
2. Yakir E. Regulation of output from the plant circadian clock / E. Yakir, D. Hilman, Y. Harir et al. // FEBS J., 2007, vol. 274, no. 2, pp. 335-345.

3. Harmer S.L. Orchestrated transcription of key pathways in Arabidopsis by the circadian clock / S.L. Harmer et al. // Science, 2000, vol. 290, no. 5499, pp. 2110-2113.

4. Chow B.Y., Kay S.A. Global approaches for telling time: omics and the Arabidopsis circadian clock / Semin. Cell Dev. Biol., 2013, vol. 24, no. 5, pp. 383-392.

5. Kim J.A. Transcriptome analysis of diurnal gene expression in Chinese cabbage / J.A. Kim et al. // Genes (Basel), 2019, vol. 10, no. 2, p. 130.

DOI 10.18699/GPB2020-19

\section{Комплекс представителей рода Trollius в биоресурсной коллекции ЦСБС СО РАН: перспективы интродукции и селекции}

Буглова Л.В. ${ }^{1}$, к.б.н., с.н.с.; Васильева О.Ю ${ }^{l}$, д.б.н., в.н.с.; Гусар А.С. ${ }^{2}$, магистрант; Козлова М.B. ${ }^{2}$, магистрант; Морозова A.O. ${ }^{2}$, магистрант.

${ }^{1}$ ФБУН «Центральный сибирский ботанический сад СО РАН» (ФГБУН ЦСБС СО РАН), Новосибирск, Россия;

${ }^{2}$ ФБОУ ВО «Новосибирский государственный аграрный университет» (ФГБОУ ВО НГАУ), Новосибирск, Россия.

e-mail: astro11@rambler.ru

В статье представлены селекционные направления работ с природными видами и формами Trollius, интродуцированными в коллекцию ЦСБС CO РАН. Для T. asiaticus и T. ledebourii установлена довольно строгая аллогамия. Приведен список природных форм. Описано потомство $F_{1}$ от искусственной гибридизации $-T$. europaeus $\times T$. asiaticus, $T$. ledebourii $\times T$. chinensis, достигшее генеративного возраста. Проводится отбор наиболее удачных фенотипических вариантов.

Ключевые слова: Trollius, виды, формы, интродукция, гибридизация.

\section{Complex of trollius forms and species in the bioresource collection of Central Siberian botanical garden Sb Ras: prospects for introduction and selection}

Buglova L.V.' ${ }^{1}$ Vasilieva O.Y. ${ }^{1}$, Gusar A.S. ${ }^{2}$, Kozlova M.V. ${ }^{2}$, Morozova A.O. ${ }^{2}$

${ }^{1}$ Federal State Institution of Science «Central Siberian botanical garden of the Siberian Branch of the Russian Academy of Sciences» (FSIS CSBG SB RAS), Novosibirsk, Russia, e-mail: astro11@rambler.ru

${ }^{2}$ Federal State Educational Institution of Higher Education "Novosibirsk State Agrarian University” (FSEI HE NSAU), Novosibirsk, Russia.

The article presents the selection research with the Trollius natural species and forms, introduced into the collection of the Central Siberian botanical garden 